\title{
ETIKA KOMUNIKASI BISNIS ONLINE DI ERA NEW NORMAL PERSPEKTIF HUKUM BISNIS ISLAM
}

\author{
Dewi Arianti, Hawari Muhammad \\ dewiarianti250995@gmail.com, hawari99aar@gmail.com
}

UIN Sunan Kalijaga Yogyakarta

\begin{tabular}{c|c|c}
\hline \hline Received: & Revised: & Aproved: \\
$05 / 03 / 2021$ & $19 / 05 / 2021$ & $22 / 05 / 2021$ \\
\hline \hline
\end{tabular}

\begin{abstract}
This article aims to determine the ethics of online business communication from the perspective of Islamic law. The research method used in this study is library research (library research) with a philosophical juridical approach, namely using the rules of Islamic law in online business practices during the covid 19 pandemic. The results show that Islamic law has regulated ideal business communication and good, by applying the basic principles of Qaulan adidan (true words), Qaulan balighan (effective and on target), Qaulan ma'rufa (kind words), Qaulan mansura (easy words), Qaulan layyina (weak words gentle), Qaulan karimah (noble words). The expected positive impact in this study is that every e-commers must provide online and communicative services to consumers, taking into account the needs proposed by consumers, especially those who have limited the covid 19 pandemic.
\end{abstract}

\section{Keywords: Business Communication Ethics, E-commerce, Islamic Law}

\begin{abstract}
Abstrak
Artikel ini bertujuan untuk mengetahui etika komunikasi bisnis online menurut prespektif hukum islam. Metode penelitian yang dugunakan dalam penelitian ini ialah library research (penelitian pustaka) dengan pendekatan penelitian Yuridis filosofis, yaitu mengunakan aturan hukum Islam dalam praktek bisnis online dalam masa pandemic covid 19. Hasil penelitian menunjukan bahwasanya dalam hukum Islam telah diatur mengenai etika berkomunikasi bisnis yang ideal dan baik, dengan menerapkan prinsip-prinsip dasar yaitu Qaulan adidan (perkataan yang benar), Qaulan balighan (efektif dan tepat sasaran), Qaulan ma'rufa (perkataan yang baik), Qaulan mansura (perkataan yang mudah dimengerti), Qaulan layyina (perkataan yang lemah lembut), Qaulan karimah (perkataan yang mulia). Dampak positif yang diharapkan dalam penelitian ini adalah setiap e commers harus bersikap transparan dan
\end{abstract}


komunikatif ketika memberikan pelayanan secara online kepada konsumen, dengan memperhatikan kebutuhan yang diajukan oleh konsumen terutama yang telah terdampak pandemic covid 19.

\section{Kata Kunci: Etika Komunikasi Bisnis, E-commerce, Hukum Islam}

\section{A. Pendahuluan}

Pada kurun hampir setahun ini Covid-19 telah menjadi wabah penyakit yang telah menyebar di seluruh dunia, tidak terkecuali di Indonesia. Adanya wabah tersebut berdampak pada aktivitas masyarakat menjadi terbatas, sehingga terbentukla suatu aturan dan upaya-upaya pencegahan agar wabah tersebut tidak semakin menyebar luas karena covid-19. Pemerintah pun telah berupaya menanggulangi wabah tersebut dengan membuat kebijakan pembatasan wilayah bagi daerah yang telah terindikasi dengan tingkat jumlah pasien covid yang tinggi. Namun dengan hadirnya kebijakan tersebut memiliki dampak bagi perekonomian masyarakat karena keterbatasan dalam beraktivitas. Oleh sebab itu pemerintah memiliki suatu kebijakan dalam rangka menyelesaikan permasalahan tersebut dengan menerapkan kebiasaan baru (New Normal), artinya melakukan kebiasaan baru dengan Batasan protokol Kesehatan sebagai upaya pencegahan penularan virus covid 19, ketika masyarakat tetap menjalani aktivitasnya seperti sedia kala.

Adanya wabah covid 19 ini membuat masyarakat mau tidak mau, harus merubah gaya hidupnya dalam aktivitas bisnis dengan mengadaptasi media online sebagai alternatifnya. Saat ini hampir semua orang merasakan perkembanganya, Tidak dapat dipungkiri lagi bahwa perkembangan dalam teknologi komunikasi sangat membantu dalam berbagi informasi dan berkomunikasi. Pada era serba online ini, teknologi komunikasi dan transaksi bisnis pun telah berkembang menjadi bagian dari e-commerce. Media sosial kini telah banyak digunakan para warga internet sebagai platform e-commerce. Berdasarkan data dari kominfo.go.id, pada tahun 2019 Indonesia masuk sebagai negara 10 terbesar dengan pertumbuhan $e$ commerce sebesar 78\% dan berada di peringkat pertama dunia. Pengguna internet di Indonesia pada tahun 2019 mencapai 82 juta orang, dan dengan pencapaian tersebut Indonesia berada di perikat kedelapan di dunia. Sedangkan untuk pengguna facebook, Indonesia menempati peringkat keempat di dunia. 
Kemajuan di bidang teknologi informasi dan komunikasi memberikan dampak berupa perubahan gaya hidup masyarakat di Indonesia. Seperti, kebiasaan berbelanja kesebuah toko offline yang kini mulai tergantikan dengan adanya $e$ commerce. Marketplace khusus untuk e-commerce pun telah menjamur di Indonesia, diantaranya: shopee, tokopedia, jd.id, bukalapak, dan lain-lain. Selain marketplace tersebut, media sosial seperti Instagram, Facebook, Twitter, WhatsApp, TikTok, pun telah menjadi platform untuk menjalankan bisnis online. ${ }^{1}$ Media sosial kini tidak hanya menjadi sarana komunikasi dan bertukar informasi saja. Media sosial Facebook misalnya, didalamnya terdapat marketplace, grup-grup jual-beli dan akun-akun pribadi yang menjual produk-produk secara online. Masyarakat kini banyak yang hidup sebagai warga inetrnet sering membuka media sosialnya, hal ini menjadikan peluang usaha untuk membuka bisnis online. Sama halnya dengan marketplace khusus e-commerce, pada media sosial pun hal-hal seperti pemasaran, tawar menawar, penjualan dan pembelian juga dapat dijalankan dengan fast respon tanpa harus bertemu secara langsung. Untuk membuka akun atau toko online di media sosial pun lebih mudah dibandingkan toko-toko offline yang memerlukan tempat dan lapak atau gedung yang memadai ${ }^{2}$. Namun, kemudahan yang dimiliki oleh media sosial kadang tidak digunakan secara bijak oleh pelaku usaha dan customer-nya. Kasus yang sering terjadi di media sosial seperti komunikasi yang berlangsung tanpa berpijak pada etika-etika sosial. Pada hakikatnya semua interaksi sosial, baik secara luring (diluar jaringan) maupn daring (didalam jaringan) memiliki aturan hukum dan etika yang harus di perhatikan.

Pada aktivitas bisnis terdapat peraturan perundang-undangan untuk mengatur hal seperti: perlindungan konsumen, larangan persaingan tidak sehat dan praktek monopoli. Sedangkan untuk bisnis berbasis online ditambahkan berupa peraturan tentang informasi dan transaksi elektronik ${ }^{3}$. Dalam Islam, aktivitas bisnis adalah bagian dari muamalah. Maka dari itu, aktivitas bisnis tidak terlepas dari hukum-

\footnotetext{
1 Aprilia Dian Evasari, Strategi Pemasaran Islam Dengan Media Sosial Untuk Meningkatkan Penjualan Produk, (Istithmar 4, no. 1, 2020), 22-49.

${ }^{2}$ Meria Agustina, Persaingan Usaha Tidak Sehat Antar Online Shop Dalam Kondisi Covid19 Terhadap Kebijakan Yang Dikeluarkan Oleh Presiden, (Res Judicata 3, no. 1, 2020), 15-25.

${ }_{3}$ Muhammad Deni Putra, Jual Beli Online Berbasis Media Sosial Dalam Prespektif Ekonomi Islam, (Iltizam Journal Of Shariah Economic Research 3, no. 2, 2019), 57-80.
} 
hukum yang mengatur segala hal berkaitan dengan masalah muamalah. Sama halnya dengan peraturan perundang-undangan yang mengatur aktivitas bisnis, etika pun merupakan bagian penting dalam aktivitas bisnis khususnya bisnis secara online.

Berbisnis dengan secara online bukanlah alasan untuk mengabaikan etika. Adapun etika-etika yang harus diperhatikan yaitu etika dalam berkomunikasi. Etika dalam berkomunikasi dalam aktivitas bisnis online terjalin ketika adanya interaksi antara penjual dan pembeli di platform e-commerce yang terjadi di kolom komentar, drive message dan inbox. Tidak sedikit aktivitas jual-beli, tawarmenawar, dan penagihan serta pembayaran dalam aktivitas bisnis online yang tidak memperhatikan etika lam berkomunikasi. Dengan banyaknya aktivitas bisnis online maka etika berkomunikasi memegang peran penting dalam pelaksanaanya ${ }^{4}$.

Seiring dengan pertumbuhan bisnis online yang kian melonjak dikarenakan masyarakat yang semakin terbiasa melakukan transaksi melalui online. Sebab itu, etika berkomunikasi sangat perlu diperhatikan untuk menghindari kesalahpahaman, pertengkaran dan perilaku dzalim antara pelaku bisnis online dan konsumen platform e-commerce. Etika dalam berbisnis merupakan ilmu yang dibutuhkan banyak pihak. Ilmu ini dibutuhkan untuk mengubah perfomen dunia bisnis yang dipenuhi oleh praktik-praktik bisnis yang dilarang atau mal-bisnis, seperti perbuatan yang melanggar hukum/bussines crimes maupun perbuatan yang melanggar etika/bussines tort ${ }^{5}$.

\section{B. Pembahasan}

\section{1) Kajian Teori}

\section{a. Etika Bisnis Dalam Perspektif Islam}

Etik atau ethics berasal dari bahasa Yunani yaitu ethos yang berarti adat, kebiasaan, watak atau perilaku, yang berlaku dalam hubungannya dengan suatu kegiatan manusia pada suatu golongan tertentu, kelompok tertentu dan budaya tertentu. Etika kadangkala disnonimkan dengan moralitas. Moralitas ialah sebuah

${ }^{4}$ Kristanto Dwi Estijayandono, Etika Bisnis Jual Beli Online Dalam Prespektif Islam, (Hukum Ekonomi Syariah 3, no. 1, 2019), 56.

${ }^{5}$ Lukman Fauroni, Rekonstruksi Etika Bisnis: Perspektif Al-Qur'an, (Iqtisad 4, no. 1, 2009), 91-106 
tindakan, yang secara moral dianggap benar, disebut tindakan yang etis ${ }^{6}$. Sedangkan etika dalam Islam dikenal dengan kata ahklak. Ahklak merupakan kata yang berasal dari bahasa Arab yaitu akhlaq, yang artinya sikap atau perangai. Menurut Imam al-Ghazali akhlak merupakan sikap yang tertanam didalam jiwa manusia, yang kemudian dapat memunculkan suatu perbuatan yang gampang dilakukan, jika sikap telah memunculkan suatu tindakan yang baik menurut akalpikiran dan dalam norma keagamaan, maka dinamai sebagai akhlak yang terpuji, namun ketika sikap memunculkan tindakan yang jahat, maka dinamai sebagai akhlak yang tercela ${ }^{7}$.

Etika dalam berbisnis dapat di defenisikan sebagai seperangkat prinsip dan norma yang harus dijalankan oleh para pelaku bisnis dalam bertransaksi, bersikap dan berelasi supaya tujuan berbisnisnya mencapai kemaslahatan. Dalam artian lain etika bisnis juga memiliki arti sebagai pemikiran tentang moralitas dalam menjalankan aktivitas bisnis, yaitu tentang perbuatan baik dan buruk, tercela dan terpuji, benar dan salah, wajardan tidak wajar, pantas dan tidak pantas, dari sikap seorang pembisnis. Sedangkan, Etika dalam berbisnis menurut hukum Islam ialah suatu kebiasaan atau moral seseorang maupun organisasi dalam melaksanakan aktivitas bisnis yang mengandung mashlahah sehingga dapat menguntungkan semua pihak sesuai dengan nilai-nilai keislaman. Dengan demikian etika bisnis Islam dapat dijadikan sebagai kerangka praktis yang dapat membentuk suatu kesadaran beragama dalam melaksanakan setiap aktivitas bisnis (religious economy pratical guidance). ${ }^{8}$.

\section{b. Prinsip-Prinsip Etika Bisnis dalam Islam}

Terdapat dua prinsip etika bisnis dalam Islam, yaitu prinsip umum dan prinsip dasar. Menurut A. Sonny Keraf, prinsip umum etika dalam berbisnis ada lima. Pertama, prinsip otonomi yang merupakan sikap dan kemampuan dalam mengambil sebuah keputusan dan tindakan berdasarkan keselarasan antara apa yang patut untuk dilakukan dan bertanggung jawab secara moral atas keputusan

\footnotetext{
${ }^{6}$ Abdul Aziz, Etika Bisnis Prespektif Islam (Bandung: Alfabeta, 2013). 24.

${ }^{7}$ Ibid, 22.

${ }^{8}$ Ibid, 26.
} 
yang telah diambil. Prinsip otonomi mengandung 3 unsur yaitu: kewajiban, kebebasan dan tanggung jawab. Kedua, Prinsip kejujuran, prinsip ini dapat dijadikan kunci keberhasilan suatu bisnis, kejujuran dalam pelaksaan kontrol terhadap konsumen, dalam hubungan antar rekan kerja dan sebagainya. Ketiga, Prinsip keadilan, pada prinsip ini setiap orang diharuskan untuk diperlakukan sama, dengan peraturan yang adil dan setiap rekan bisnis diperlalukan sesuai dengan haknya masing-masing sehingga tidak ada yang merasa dirugikan. Keempat, Prinsip saling menguntungkan, dalam dunia bisnis yang penuh dengan persaingan, prinsip ini menuntut supaya dalam melaksanakan aktivitas bisnis tidak ada pihak yang merasa tidak diuntungkan sesuai prestasi masing-masing (win-win solution). Kelima, Prinsip integritas moral, prinsip ini menekankan pada tuntutan dari dalam diri si pelaku (inner beauty), harus menjaga nama baik perusahaan tetap dipercaya dan menjadi perusahaan terbaik ${ }^{9}$.

Sedangkan prinsip- Prinsip Dasar atau asas-asas etika bisnis dalam Islam dibagi menjadi lima. Pertama, Kesatuan (Unity), tereflekasikan kedalam konsep Tauhid, yaang merupakan perpaduan keseluruhan dari aspek kehidupan muslim baik dalam melaksanakan aktivitas perekonomian, sosial dan politik sehingga menjadikannya keseluruhan yang homogen, serta mementingkan konsep konsistensi dan keteraturan yang menyeluruh. Kedua, Keseimbangan (Equilibrium / al-adl), Islam selalu mengajarkan untuk selalu bersikap adil kepada siapapun bahkan pada pihak yang tidak disukai. Ketiga, kebebasan (Free Will / ikhtiyar), kebebasan disini dimaksudkan sebagai kebebasan yang tidak merugikan kepentingan bersama. Tidak ada batasan untuk seseorang dalam berkarya maupun bekerja dengan segala potensi yang dimilikinya. Dengan kecenderungan manusia yang ingin terus-menerus memenuhi kebutuhan hidupnya yang tidak terbatas, namun dikendalikan dengan adanya kewajiban bagi setiap individu untuk melaksanakan zakat, infak, dan bersedekah. Keempat, Tanggung jawab (Responsibility / fardh), kebebasan harus disertai dengan rasa tanggung jawab agar terciptanya keadilan dan kesatuan. Secara logis, prinsip tanggung jawab 
berhubungan erat dengan kebebasan bertindak. Ketertkaitan tersebut ialah untuk menetapkan batasan mengenai kebebasan apa yang boleh dilakukan oleh manusia yang kemudian di sertai dengan tanggung jawab atas apa yang dilakukannya. Kelima, kebenaran (kebajikan dan kejujuran), kebenaran dapat diartikan sebagai niat, sikap, dan perilaku yang benar dalam transaksi, dalam mencari dan memperoleh relasi bisnis ataupun dalam upaya untuk meraih keuntungan. Dengan adanya prinsip kebenaran ini, menjadikan etika berbisnis dalam Islam sangat menjaga dan mencegah adanya kemungkinan kerugian bagi salah satu pihak dalam melakukan transaksi, bekerjasama, maupun dalam melakukan perjanjian bisnis. ${ }^{10}$

\section{c. Etika Komunikasi Bisnis}

Komunikasi merupakan kata yang berasal dari bahasa Latin yaitu ‘communis” yang dalam berarti sama, sama maknanya dan artinya. Menurut Onong U. Effendy, komunikasi ialah proses menyampaikan pesan tertentu dari seseorang kepada orang lainnya, atau untuk mempengaruhi seseorang baik langsung dengan secara lisan, maupun tidak langsung dengan secara media sehingga terjadilah perubahan sikap, tindakan, pendapat atau perilaku ${ }^{11}$. Komunikasi dalam berbisnis terjadi apabila pesan verbal dan nonverbal dikirim dan diterima untuk diberikan makna bersama. Jika pesan-pesan yang dikirim dan diterima dalam menjalankan bisnis mengikuti etika yang tidak menyinggung para pembisnis maka bisnis itu mengandung komunikasi yang etis (pantas). Komunikasi bisnis yang etis memiliki signifikansi pada tiga bidang utama dari relasi bisnis, relasi bisnis dengan aktivitas bisnis dan aktivitas bisnis dengan masyarakat. Ketiga relasi tersebut menjadi beretika bisnis jika melaksanakan etika komunikasi yang saling menyenangkan.

Adapun tujuan dari etika komunikasi dalam bisnis adalah untuk melindungi, menghormati, menjaga citra publik yang baik. Karena, kesalahpahaman umun berkomunikasi dalam bisnis adalah komunikasi yang tidak jelas dan tidak transparan, komunikasi yang baik sejatinya berdasarkan persamaan persepsi. Jika terdapat pihak yang menafsirkan kata-kata atau tindakan secara lain maka terjadilah

${ }^{10}$ Ngorang Philipus, Komunikasi Bisnis Yang Etis: Sebuah Tinjauan Kritis, (Komunikasi Dan Bisnis 6, no. 2, 2018), 46. 1992), 60 .

${ }^{11}$ Onong Uchjana Effendy, Dinamika Komunikasi (Bandung: PT. Remaja Rosdakarya, 
komunikasi yang melahirkan diskriminatif atau menyinggung, terjadinya miskonsepsi sehingga menganggap komunikasi tersebut tidak etis.

Menurut Neil Kokemuller, sekurang-kurangnya ada tiga tujuan etika dalam komunikasi bisnis. Pertama, komunikasi internal, yaitu komunikasi yang tejadi didalam perusahaan yang bertujuan untuk menumbuhkan hubungan kerja yang baik dan kerja sama tim. Berkomunikasi dalam dunia bisnis, profesionalisme, rasa hormat dan kebijaksanaan sangatpenting demi mendukung komunikasi internal yang etis. Kedua, komunikasi eksternal, yaitu komunikasi yang berlangsung antara pihak lembaga dengan pihak luar, seperti: mitra bisnis, pemasok, dan pasar perusahaan. Komunikasi bisnis ini terjadi pada saat melakukan iklan, promosi, dan hubungan dengan masyarakat. Unsur etika utamanya adalah integritas, kredibilitas dan konsistensi. Dan yang ketiga, benefit, komunikasi bisnis tentu saja bertujuan untuk mendapatkan keuntungan, keuntungan nama baik, kesetiaan pelanggan yang mendatangkan keuntungan keuangan bagi bisnis yang dikelola ${ }^{12}$.

Komunikasi bisnis pada umumnya dilakukan dengan dua cara yaitu verbal dan nonverbal. Komunikasi verbal, yaitu komunikasi yang dilakukan melalui lisan maupun tulisan, dimana bentuknya dibagi menjadi dua yaitu aktif (berbicara dan menulis) dan pasif (mendengarkan dan menulis). Sedangkan komunikasi nonverbal, yaitu komunikasi yang disampaikan tanpa menggunakan kata-kata, contohnya: simbol-simbol, sandi, warna, ekspresi wajah dan gerakan tubuh. Komunikasi dalam berbisnis bertujuan untuk memberikan informasi (informing), persuasi/ mempengaruhi, dan melakukan kolborasi/kerjasama dengan pelanggan. Komunikasi bisnis pun berlaku untuk komunikasi pada media sosial. Media sosial merupakan salah satu sarana berinteraksi yang dilakukan dengan berbagi informasi dan gagasan melalui jaringan internet untuk membentuk sebuah komunitas virtual. Media sosial juga dapat diartikan sebagai sekelompok aplikasi yang berbasis internet berdasarkan ideologi web 2.0 untuk memungkinkan orang ke orang lain melakukan komunikasi secara mobile sehingga dapat menciptakan dan bertukar konten (user-generated content) ${ }^{13}$. Saat ini media sosial telah menjadi salah satu

\footnotetext{
${ }^{12}$ Alo Lliliweri, Konumikasi Antar Personal (Jakarta: Kencana, 2015). 75.

13 Arumi Wahyuni Purbohastuti, Efektivitas Mediasosial Sebagai Media
} 
platform bisnis. Maka dari itu, agar komunikasi dalam berbisnis pada media sosial dapat berjalan dengan baik, ada etika-etika komunikasi dalam Islam yang harus diterapkan ${ }^{14} \cdot{ }^{15}$ Adapun etika komunikasi tersebut adalah sebagai berikut:

1. Qaulan sadidan (perkataan yang benar)

Kata “qaulan sadidan” disebutkan dua kali dalam Al-Qur’an. Pertama, Allah mememrintahkan umat manusia untuk menyampaikan qaulan sadidan (perkataan yang benar) dalam urusan anak yatim dan keturunan, dalam Surah An-Nisa Ayat 9. Kedua, Allah memerintahkan qaulan sadidan sesudah taqwa, dalam Surah Al-Ahzab Ayat 70. Wahbah al-Zuhaily mendefenisikan qaulan sadidan sebagai perkataan yang benar dan bertanggung jawab, yaitu perkataan yang tidak bertentangan dengan ajaran Islam. Ia juga mengartikan surah alAhzab ayat 70 merupakan perintah Allah terhadap dua hal: perintah untuk melaksana kan ketaatan dan ketaqwaan dan menjauhi larangan-Nya, dan Allah memerintahkan orang-orang yang beriman untuk berucap dengan qaulan sadidan, yaitu ucapan yang baik dan sopan tidak kurang ajar, ucapan yang benar dan bukan yang batil ${ }^{16}$.

2. Qaulan balighan (efektif, tepat sasaran)

Kata "baligh" dalam bahasa Arab berarti tepat sasaran atau mencapai tujuannya. Jika dikaitkan dengan qaul (perkataan ataupun komunikasi), “balighan” berarti jelas maksudnya, maknanya, tepat dalam memakai kata. Jalaluddin Rahmat mendefenisikan qaulan balighan sebagai menggunakan perkataan yang tepat sasaran, mudah dimengerti, langsung pada pokok masalah (straight to the point), yang efektif dan tidak berbelit-belit atau bertele-tele dalam menyampaikan maksud ${ }^{17}$. Oleh sebab itu, agar sebuah komunikasi dapat mencapai ketepatan sasaran, maka gaya alam berbicara dan pesan yang akan disampaikan haruslah disesuaikan dengan kadar kemampuan yang dimiliki

Promosi,(Tirtayasa EKonomika 12, no. 2, 2017), 214. 2016), 115-26.

${ }_{4}$ Muslimah, Etika Komunikasi Dalam Perdagangan Islam,(Sosial Budaya 13, no. 2,

${ }^{16}$ Wahbah Zuhaily, Tafsir Munir (Beirut: Dar Al-Fikr, 1991). 260.

${ }^{17}$ Cahya Agung Nugraha, Ikin Asikin, and Asep Dudi Suhardini, Etika Komunikasi Siswa Kepada Guru Dalam Perspektif Aktivitas Kelompok Remaja Islam Di SMA PGII 2 Bandung, (Istithmar 4, no. 1, 2020), 27-35, https://doi.org/10.29313/.v1i01.7188. 
komunikan, serta menggunakan bahasa yang dimengerti oleh para komunikan.

3. Qaulan ma'rufa (perkataan yang baik)

Kata qaulan ma'rufa berarti perkataan atau ucapan yang baik dan pantas. Qaulan Ma'rufa juga memiliki makna komunikasi yang bermanfaat akan menimbulkan kebaikan (maslahat). Sebagai pelaku bisnis dalam berkomunikasi, haruslah menjagaa perkataan, perkataan apapun yang diucapkan harus selalu mengandung nasihat dan menenangkan hati bagi orang yang mendengarnya. Tidak diperkenankan untuk mencari-cari kejelekan atau kekurangan orang lain, dengan hanya bisa mengkritik ataupun mencari-cari kesalahan orang lain, dan memfitnah serta menghasut ${ }^{18}$.

4. Qaulan maisura (perkataan yang mudah dimengerti)

Kata maisura berasal dari pada kata yasara, dimana secara etimologi berarti mudah atau pantas. Jalaluddin Rakhmat berpendapat bahwa qaulan maisura merupakan ucapan yang menyenangkan lawan bicaranya ialah ucapan yang menyulitkan. Ketika qaulan ma'rufa merupakan berkomunikasi dengan perkataan yang baik, maka qaulan maisura merupakan pekataan yang menggembirakan dengan mengucapkan perkataan yang mudah dan pantas. Dalam dunia bisnis berkomunikasi dengan mengucapkan qaulan maisura berarti menyampaikan perkataan dengan kata-kata yang sederhana, mudah dimengerti dan mudah dipahami tanpa harus berpikir lama ${ }^{19}$.

5. Qaulan layyina (perkataan yang lemah-lembut)

Pada al-Qur' an QS. Thaha ayat (44) telah dijelaskan bahwa Allah SWT. memerintahkan Nabi Musa as. dan Harun as. untuk berbicara dengan kelemahlembutan dan tidak berkata kasar kepada Fir'aun. Qaulan Layyina secara harfiah memiliki arti komunikasi yang lemah-lembut, dengan suara yang nyaman didengar, dan dengan penuh keramah-tamahan, sehingga dapat menenangkan hati. Lawan dari perkataan yang lemah-lembuat dan sekaligus tidak boleh kita lakukan adalah mengeraskan suara, seperti meninggikan suara

${ }^{18}$ Mafri Amir, Etika Komunikasih Masa Dalam Pandangan Islam (Jakarta: Logos, 1999).

${ }^{19}$ Ibid. 90 
atau berteriak dan membentak. Siapapun tidak aka senang berkomunikasi dengan orang-orang yang kasar tutur katanya. Rasullulah SAW. pun selalu menjaga tutur katanya dengan kata-kata yang lemah lembut, sehingga setiap kata yang diucapkannya sangat menyejukkan hati siapapun yang mendengarnya 20 .

6. Qaulan karimah (perkataan yang mulia)

Islam selalu menasihati untuk membiasakan menggunakan ucapapan yang mulia dalam berbicara kepada lawwan bicara tanpa terkecuali . Qaulan sadidan ini merupakan bentuk komunikasi yang dimana perkataan-perkataan yang dikeluarkan adalah kata-kata yang sopan dan santun, tidak menggurui. Dalam Islam kita telah dianjurkan untuk berkomunikasi dengan qaulan karimah dan dilarang untuk mengelurkan perkataan yang menghina dan mengolok-olok hingga menyakiti perasaan orang lain ${ }^{21}$.

\section{d. Etika Bisnis Pada Media Sosial}

Bisnis merupakan kegiatan relasional, bisnis tidak pernah terjadi atau dioperasikan secara sepihak. Bisnis selalu bersiat other directtedness atau selalu memiliki keterarahan kepada yang lain. Keterarahan yang dimasuk dalam hal ini ialah seperti pemasok, pelanggan dan mitra bisnis, maka secara hakiki bisnis merupakan inetraksi di antara palin kurang dua pihak yang memiliki kepentingan yan sama, yakni sama-sama menguntungkan. Jadi, Interaksi dalam dunia bisnis merujuk kepada kegiatan yang hanya terjadi dalam suatu jaringan yang memiliki kepentingan yang sama. Dalam bisnis semua pihak yang berkepentingan selalu berprinsip “do ut des” atau saya memberikan hal ini ini agar engkau memberikan juga memberikan kepadaku sesuatu. Bisnis selalu berkaitan dengan persoalan untung-rugi. Hal yang ditargetkan dalam bisnis adalah untung, bahkan memaksimalisasi keuntunngan (maxziming profit) ${ }^{22}$.

Setiap muslim yang berbisnis haruslah memperhatikan aturan hukum Islam (syariah) ketika bermuamalah atau melakukan aktivitas bisnis, termasuk berbisnis

${ }^{20}$ Hamka, Tafsir Al-Azhar Juz 21 (Jakarta: Pustaka Panji Mas, 1984). 135.

${ }^{21}$ Ibid, 85.

${ }^{22}$ Norvadewi, Bisnis Dalam Prespektif Islam (Telaah Konsep, Prinsip Dan Landasan Normatif), (Al-Tijary 1, no. 1, 2015), 33-46. 
melalui media sosial. Ini dikarenakan tujuan bisnis dalam islam selain mencari keuntungan materi, juga untuk mendapat keberkahan dari dai harta (maal) yang diperoleh. Keberkahan akat didapat apabila harta tersebut didapatkan dan diklola sesuai dengan ketentuan syariah. Karena prinsip bisnis di dunia maya sama seperti di dunia nyata, aturan bisnisnya secara umum sama.

\section{e. Praktik Mal-Bisnis}

Praktik mal-bisnis adalah bisnis yang bertentangan dengan nilai-nilai etika, karena mengandung unsur kebathilan, kerusakan dan kedzaliman ${ }^{23}$. Adapaun praktik mal bisnis tersebut adalah sebagai berikut:

1. Penipuan (al-Gabn dan tadlis)

Penipuan dapat dilakukan dengan berbagai cara salah satunya, yaitu penipuan harga dari sebuah produk sebenarnya dengan maksud mengelabui pembeli dan penipuan dari penyerahan barang yaitu tidak menempati janjinya. Dalam berhubungan dengan rekan bisnis, setiap pebisnis muslim dalam berakad, haruslah sesuai dengan kenyataan tanpa manipulasi. Misalnya, memberikan sampel produk dengan kualitas yang sangat baik, padahal yang dikirimkan itu memiliki kualitas jelek ${ }^{24}$.

2. Melakukan Combe

Praktek combe merupakan lawan dari ba'i najasy yaitu penjual bekerja sama dengan orang lain agar berpura-pura melakukan penawaran dengan harga tinggi sehingga orang lain tertarik untuk menawarnya ${ }^{25}$. Dengan begitu combe berarti berpura-pura melakukan penawaran serendahrendahnya sehingga orang lain tertarik untuk membelinya.

3. Pemberian harga diatas atau dibawah harga pasar

Bagi seorang muslim persaingan adalah berebut menjadi yang terbaik, terbaik dalam produk yang bermutu, harga bersaing "tidak membanting harga, maupun merugikan konsumen”, dan dengan melakukan

\footnotetext{
${ }^{23}$ Sri Husnul Khotimah Ulul Azmi, Andias, Nita Ambar Sari, Efektivitas Entepreneurship Rosulullah SAW Pada Transaksi Bisnis Islam DI Era Modern, (As-Salam VII, no. 2 2018), 233-46.

24 Abdul Latif, Etika Persaingan Dalam Usaha Menurut Pandangan Islam, (Islamic Economics Journal 3, no. 2, 2017), 161, https://doi.org/10.21111/iej.v3i2.2717.

${ }^{25}$ Ibid, .
} 
pelayanan yang terbaik. Dalam al-Qur'an QS. An-Naba': 10-11, bahwasannya Allah SWT berfirman:

$$
\text { وجعلنا اليل لباسا. وجعلنا النهار معاشا. }
$$

4. Ta'sir (Penetapan Harga)

Tas'ir atau penetapan harga merupakan standar pasar yang ditetapkan oleh pemerintah atau yang berwenang, untuk disosialisasikan secara paksa kepada masysrakat dalam jual beli. Tas'ir adalah salah satu praktek yang dilarang oleh Islam, pemerintah atau yang berwenang tidak memiliki hak dalam menentukan harga tetap pada sebuah komoditas, kecuali apabilan mereka telah menyediakan para pedagang jumlah yang cukup untuk dijual dengan menggunakan harga yang ditetapkan tersebut dengan melihat dan menemukan adanya kezaliman didalam sebuah pasar yang mengakibatkan rusaknya mekanisme pasar yang sehat ${ }^{26}$.

5. Praktek monopoli

Baik Islam maupun pemerintah sama-sama melarang praktek ini, hal ini terdapat dalam undang-undang no 5 tahun 1999 tentang larangan praktek monopoli dan persaingan tidak sehat. Praktek monopoli merupakan perbuatan yang memusatkan kekuatan ekonomi yang dilakukan salah satu atau lebih pelaku usaha yang mengakibatkan dikuasainya suatu produksi atau pemasaran atas barang dan jasa tertentu sehingga menimbulkan adanya persaingan usaha yang tidak sehat sehingga merugikan kepentingan umum 27.

Selain hal-hal diatas, praktik mal bisnis yang dilarang dalam islam lainnya adalah riba, mengurangi timbangan atau takaran, gharar dan maysir, penimbunan (ihtikar), skandal, korupsi dan kolusi, serta oligopoli ${ }^{28}$.

\section{2) Meodologi Penelitian}

Dalam proses penulisan jurnal ini penulis menggukan metode deskripsi kualitatif. Adapun jenis penelitianyang digunakan adalah Library Reseach

\footnotetext{
${ }^{26}$ Mardani, Fiqih Ekonomi Syariah : Fiqih Muamalah (Jakarta: Kencana, 2012). 15.

${ }^{27}$ Ibid. 15.

${ }^{28}$ Latif, Etika Persaingan Dalam Usaha Menurut Pandangan Islam. 171.
} 
(Peneltian Kepustakaan). Mengkaji konsep etika komunikasih bisnis online di masa pandemic covid 19 dari sudut pandang hukum islam. Adapun materi hukum islam yang digunakan adalah akhlakh di dalam berbicara sebagai seorang muslim.

\section{3) Hasil Penelitian}

\section{a. Etika Komunikasi Bisnis Syariah Pada E-Commers (Bisnis Online)}

E-Commers merupakan solusi yang terbaik bagi pelaku usaha dan calon konsumen untuk dapat bertemu dalam melaksanakan aktifitas usha maupun perdagangan berbasis online tanpa harus adanya transaksi tatap muka. Kemudahan, kecepatan, efisiensi, dan keamanaan juga menjadi perhatian lebih pada suatu aktivitas bisnis, E-Commers yang telah memberikan ruang bagi para pelaku bisnis untuk melakukan kegiatan usahanya secara online (daring) dengan aman dan nyaman. Salah satu dari bentuk kemudahan yang didapatkan secara langsung adalah dengan berdagang melalui market place, bahwa penjual tidak perlu harus mencari tempat secara khusus (Toko, Tanah Dan Bangunan), namun dengan adanya market place sebagai salah satu e-commers dapat menciptakan toko online bagi para penjual. Sehingga terjadilah suatu aktivitas usaha berbasis online.

\section{b. Etika Bisnis dan Perlindungan Terhadap Konsumen}

Perkembangan $e$-commers harus sejalan beriringan dengan peraturan yang telah berlaku di lapangan. Bersamaan dengan Undang-Undang Nomor 11 Tahun 2008 Tentang Informasi dan Transaksi Elektronik, bahwasannya Undang-undang ini telah hadir dalam rangka menggatur aktivitas masyarakat di dunia maya baik di sosial media dan kegiatan masyarakat secara umum berbasis online. Maka dari pada itu undang-undang ini hadir untuk menjaga agar tidak disalah gunakan untuk perbuatan melawan hukum.

Berkaitan dengan Probelmatika keamanan dalam bertransaksi, data pribadi pelanggan, dan pelayanan yang baik merupakan hal yang harus dicermati oleh pelaku usaha. dengan etika dalam berkomunikasih dan perlindungan konsumen yang menggunakan jasa dari salah satu ecommers seperti market place: shopee, Tokopedia, blibli, bukalapak dan lain sebagainya. Hal yang harus diperhatikan dalam aktivitas di market place yang berkaitan dengan problem tersebut adalah cara berkomunikasih dengan calon pembeli, ketepatan waktu dalam proses pengiriman, 
dan kualitas barang yang diperdagangkan benar harus sesuai dengan gambar yang telah ditampilkan.

Ketika suatu pelayanan itu baik dari cara komunikasi yang responsif dari penjual atau pelapak, dan Deskripsi lengkap terkait kondisi barang dagangan yang sesuai dengan tampilan gambar yang telah dipaparkan, Hal ini sudah bisa dapat dikatakan sebagai implementasi dari etika bisnis. Dengan demikian dapat memberikan rasa aman dan kenyamanan bagi para calon pembeli untuk mendapatkan jaminan kepercayaan kepada pelapak terhadap barang yang telah dibelinya secara online. Membangun komunikasi dan pelayanan yang baik agar mendapatkan kepercayaan dari calon pembeli.

Berbicara tentang jaminan keamanan atas suatu barang dagangan. Pada beberapa market place seperi shopee, Tokopedia, bukalapak dan lain sebagainya, telah memberikan penawaran asuransi atas barang yang akan dikirimkan kepada pembeli. Dengan adanya penawaran tersebut merupakan suatu upaya dari contoh etika dalam hal memberikan pelayaan yang baik untuk menjaga barang dagangannya agar tetap selalu dalam kondisi aman pada proses pengirimannya.

\section{c. Etika Bisnis Dalam Persaingan Usaha di Market Place}

Dalam suatu usaha tentu saja tidak hanya satu orang saja yang memiliki usaha, Ada banyak Sebagian dari masyarakat di Indonesia memiliki usaha yang sama dalam suatu bidang usaha tertentu. Dengan adanya hal tersbut tentu telah ditetapkan suatu aturan dan etika dalam persainagan usaha. Sehingga harapannya adalah bisa menciptakan keadilan dan kesatabilan dalam dunia usaha tersebut. Hal ini juga berlau di market place yang berkaitan dengan dropship.

Dapat kita temui beberapa fenomena di market palce seperti shopee, Tokopedia, bukalapak dan lain sebagainya, bahwa dalam display produknya dapat ditemukan kesamaan gambar foto produk terntu diantara beberapa penjual di market place tersebut. Akibatnya Ketika kita hendak memilih produk tertentu kita menemui satu jenis produk yang sama namun berbeda penjual dan harganya. Hal ini bisa dikatakan masuk dalam wilayah persaingan usaha.

Hal tersebut menjadi dilema bagi calon pembeli yang hendak melakukan pembelian lantaran terdapat banyak foto produk yang sama namun berbeda 
penjualan dan harganya. Disisi lain dengan terjadinya ini Sebagian dari pelapak utama (pemilik produk) merasa dirugikan dengan adanya perilaku ini. Lantaran telah mengambil foto produknya untuk digunakan oleh pelapak lainnya.

Seyogyanya dalam etika bisnis dalam persainagan usaha, melihat hal ini dapat diselesaikan dengan cara persuasif antar pelapak. Pelapak kedua meminta izin kepada pelapak utama untuk menggunakan foto produknya sebagai display di tokonya. Dengan catatan ia harus mengambil produk di pelapak utama, atau juga bisa dengan kesepakatan lainnya. Adanya kommuikasi bisnis yang baik ini bisa membantu dalam persoalan persaingan usaha. Sehingga dengan dijunjungnya etika bisnis dan etika persaingan usaha ini harapannya dapat mewujud keadilan dan kesejahteraan baik bagi penjual maupun pembeli.

\section{Kesimpulan}

Pandemi covid 19 telah membuat perubahan dalam setiap aktivitas masyarakat di Indonesia khususnya dalam aktivitas bisnis. Aktivitas bisnis online atau berbasis daring pada ecomers, sangat perlu menjunjung etika komunikasi bisnis yang baik dan benar. Hal ini dilakukan dengan harapan agar dapat menjamin kelancaran dan kesuksesan dalam menjalankan aktivitas bisnis. Ketika etika berkomunikasi dalam berbisnis tidak dijalankan atau diterapkan dengan penuh komitmen maka terdapat potensi terjadinya kegagalan dalam menjalankannya, dan tidak menutup kemungkinan terdapat pihak-pihak yang dirugikan akibat komunikasi bisnis yang tidak baik tersebut, oleh karenanya dengan menerapkan dan menjaga prinsip dasar dalam etika-etika berkomunikasi dalam Islam seperti; Qaulan sadidan (perkataan yang benar), Qaulan balighan (perkataan yang efektif atau tepat sasaran), Qaulan ma'rufa (perkataan yang baik), Qaulan maisura (perkataan yang mudah dimengerti), Qaulan layyina (perkataan yang lemahlembut), Qaulan karimah (perkataan yang mulia). Kelima qaulan tersebut merupakan suatu usaha berkomunikasi dengan berpegang pada etika-etika komunikasi Islam dalam menjalankan aktivitas bisnis berbasis online (daring) untuk mencapai target yang diharapkan, mencapai kemaslahatan dan juga meraih keberkahan. 


\section{DAFTAR PUSTAKA}

Agustina, Meria. "Persaingan Usaha Tidak Sehat Antar Online Shop Dalam Kondisi Covid-19 Terhadap Kebijakan Yang Dikeluarkan Oleh Presiden.” Res Judicata 3, no. 1 (2020): 15-25.

Amir, Mafri. Etika Komunikasih Masa Dalam Pandangan Islam. Jakarta: Logos, 1999.

Aprilia Dian Evasari. "Strategi Pemasaran Islam Dengan Media Sosial Untuk Meningkatkan Penjualan Produk.” Istithmar 4, no. 1 (2020): 22-49.

Aziz, Abdul. Etika Bisnis Prespektif Islam. Bandung: Alfabeta, 2013.

Effendy, Onong Uchjana. Dinamika Komunikasi. Bandung: PT. Remaja Rosdakarya, 1992.

Fauroni, Lukman. “Rekonstruksi Etika Bisnis: Perspektif Al-Qur’an.” Iqtisad 4, no. 1 (2009): 91-106. https://doi.org/10.20885/iqtisad.vol4.iss1.art6.

Hamka. Tafsir Al-Azhar Juz 21. Jakarta: Pustaka Panji Mas, 1984.

Keraf, A. Sonny. Etika Bisnis Tuntutan Dan Relevansinya. Yogyakata: Kanisius, 1998.

Kristanto Dwi Estijayandono, Dkk. "Etika Bisnis Jual Beli Online Dalam Prespektif Islam.” Hukum Ekonomi Syariah 3, no. 1 (2019): 56.

Latif, Abdul. "Etika Persaingan Dalam Usaha Menurut Pandangan Islam.” Islamic Economics Journal 3, no. 2 (2017): 161. https://doi.org/10.21111/iej.v3i2.2717.

Lliliweri, Alo. Konumikasi Antar Personal. Jakarta: Kencana, 2015.

Mardani. Fiqih Ekonomi Syariah : Fiqih Muamalah. Jakarta: Kencana, 2012.

Muhammad Deni Putra. “Jual Beli Online Berbasis Media Sosial Dalam Prespektif Ekonomi Islam.” Iltizam Journal Of Shariah Economic Research 3, no. 2 (2019): 57-80.

Muslimah. “Etika Komunikasi Dalam Perdagangan Islam.” Sosial Budaya 13, no. 2 (2016): 115-26.

Norvadewi. "Bisnis Dalam Prespektif Islam (Telaah Konsep, Prinsip Dan Landasan Normatif).” Al-Tijary 1, no. 1 (2015): 33-46. 
Nugraha, Cahya Agung, Ikin Asikin, and Asep Dudi Suhardini. "Etika Komunikasi Siswa Kepada Guru Dalam Perspektif Aktivitas Kelompok Remaja Islam Di SMA PGII 2 Bandung.” Istithmar 4, no. 1 (2020): 27-35. https://doi.org/10.29313/.v1i01.7188.

Philipus, Ngorang. "Komunikasi Bisnis Yang Etis: Sebuah Tinjauan Kritis.” Komunikasi Dan Bisnis 6, no. 2 (2018): 46.

https://scholar.google.com/scholar?start=30\&q=jurnal+bentuk+komunikasi+ bisnis\&hl=id\&as_sdt=0,5\#d=gs_qabs\&u=\%23p\%3DhdkKEFFg8u0J.

Purbohastuti, Arumi Wahyuni. "Efektivitas Mediasosial Sebagai Media Promosi." Tirtayasa EKonomika 12, no. 2 (2017): 214.

Ulul Azmi, Andias, Nita Ambar Sari, Sri Husnul Khotimah. "Efektivitas Entepreneurship Rosulullah SAW Pada Transaksi Bisnis Islam DI Era Modern.” As-Salam VII, no. 2 (2018): 233-46.

Zuhaily, Wahbah. Tafsir Munir. Beirut: Dar Al-Fikr, 1991. 